\title{
AZ ÉTKEZÉSI TOJÁSTERMELÉSBEN ALKALMAZOTT TARTÁSTECHNOLÓGIÁK FENNTARTHATÓSÁGI KÉRDÉSEI
}

\section{SUSTAINABILITY ASPECTS OF DIFFERENT TABLE EGG PRODUCTION SYSTEMS}

\author{
Molnár Szilvia ${ }^{1}$, Szőllősi László ${ }^{2}$ \\ 1,2Üzemtani és Vállalati Tervezés Tanszék, Gazdaságtudományi Kar, Debreceni Egyetem, Magyarország
}

\author{
Kulcsszavak: \\ étkezési tojás \\ nemketreces tartásmód \\ élelmiszerbiztonság \\ fogyasztói attitűdök \\ Keywords: \\ table eggs \\ non-cage system \\ food safety \\ consumer attitudes
}

\begin{abstract}
Összefoglalás
Ma már egyre inkább ismert az étkezési tojás pozitív hatása, az anyatejhez hasonló, teljes biológiai értékü fehérjéket tartalmazó élelmiszer. Miután relatíve olcsó, magas tápértékü komplex táplálékforrás, az emberi szervezet napi állatifehérje-szükséglete a legolcsóbban és a legkisebb környezeti terhelés mellett a tojással fedezhetö. Hasonlóan más élelmiszerekhez, a tojással kapcsolatos fogyasztói igények is jelentősen változtak az elmúlt években, egyre inkább elötérbe kerül az állatjólét, valamint az egészség- és környezettudatosság, s ennek okán egyre több kérdés merül fel a különböző tartásmódokkal, különösképpen a ketreces rendszerekkel kapcsolatosan. Ennek kapcsán a tanulmány célja, hogy megvizsgálja a különböző tartásmódok fenntarthatóságbeli kérdéseit, valamint a fogyasztók egészségére és tojásfogyasztásra ható tényezőit, a releváns nemzetközi szakirodalmak és adatbázisok szintetizálása révén.
\end{abstract}

\section{Abstract}

Today, the positive effects of table eggs are increasingly known, it is a food similar to breast milk with full biological value. As a relatively inexpensive, highly nutritious complex food source, the animal protein requirement of the human body can be met with eggs in the cheapest and lowest environmental impact. As with other foods, consumer needs for eggs have changed significantly in recent years, animal welfare, health and environmental awareness becoming more prominent, leading to more and more questions about different production systems, especially cage systems. For this reason, the aim of this study to examine the sustainability issues of different production systems of table egg, as well as the factors affecting consumer health and egg consumption through the synthesis of relevant international literature and databases.

\section{Bevezetés}

Az EU28 tojástermelőinek számos kihívással kellett szembenézniük az elmúlt évtizedben. Az 1999/74/EK irányelv és a hozzákapcsolódó rendeletek értelmében 2012-től az EU tagországaiban a tojótyúkokat csak EU-konform feljavított ketrecekben vagy nem-ketreces tartásmódokban lehet

\footnotetext{
1 Kapcsolattartó szerző.

E-mail cím: molnar.szilvia@econ.unideb.hu
} 
tartani és a forgalomba hozott tojások is csak ilyen rendszerekből származhatnak. A ketreces rendszerek esetében hagyományos és EU-konform feljavított vagy berendezett ketreceket különböztethetünk meg, míg a nemketreces rendszerek esetében mélyalmos (egyszintes), madárházas (többszintes), valamint szabad- és ökológiai tartásmódot különíthetünk el. A feljavított vagy berendezett ketrecekben a tojótyúkok számára nagyobb ketrecterület, valamint további, a tojótyúkok természetes igényeinek kielégítését szolgáló eszközök biztosítása szükséges, szemben a korábban alkalmazott hagyományos ketrecekkel [59]. A hétköznapi szóhasználatban, de esetenként a szakirodalmakban is alternatív tartásmódként azonosítják a nemketreces rendszereket, azonban előbbi kifejezés alatt a mélyalmos és madárházas (volier) technológiát értjük.

Az elmúlt évtizedben a makrogazdasági tényezők változása mellett, a fogyasztói igények is jelentősen átalakultak. Napjaink vásárlói egyre nagyobb hangsúlyt fektetnek arra, hogy mit esznek, s mindez milyen módon befolyásolja az egészségüket, s egyre inkább előtérbe kerülnek az olyan tényezők, mint a fenntartható és az állatjól(l)éti szempontokat figyelembevevő módon történő előállítás fontossága. Ennek hatására - különösen az EU28 tagországaiban - a fogyasztók egyre gyakrabban vásárolnak nemketreces tartásmódból származó tojást, mert úgy vélik, hogy az ily módon előállított tojás jobb minőségű, mint a ketreces rendszerben előállított termékek [14]. A ketreces tartásmód egyre inkább vitatéma az állatok jólétét és védelmét támogatók, valamint a kutatók és a termelők körében [26]. Ennek okán 2018-ban az unióban elindult egy, a ketreces tartásmódok beszüntetését célzó polgári kezdeményezés (End the Cage Age). Az ehhez kapcsolódó aláírásgyűjtés 2019 szeptemberében 1,4 millió aláíással lezárult, melyet az Európai Bizottság 2020 őszétől érvényes kezdeményezésként tart számon, s idővel hivatalosan is állást kell foglalnia a kérdésben. Ehhez kapcsolódóan az elmúlt időszakban több kereskedelmi lánc is bejelentette Európában, hogy a terveik szerint 2025-től nem értékesítenek ketreces tartásmódból származó tojást üzleteikben, s mindez jelentős mértékben befolyásolhatja a tojáságazat helyzetét azokban a tagországokban, ahol a termelők jellemzően ketreces tartásmódot alkalmaznak. Az EC (2020) [12] adatai szerint 2019-ben a tojótyúkok 47,8\%-a feljavított ketreces tartásmódban, 29,3\%-a mélyalmos, illetve madárházas (volier) rendszerben, 17,0\%-a szabadtartásban termelt, míg az ökológiai tartás aránya mindössze 5,9\% volt. Azonban az egyes tagországokban ezek aránya eltérően alakul. Málta, Litvánia, Portugália, Szlovákia, Lengyelország és Lettország termelői a tojótyúkok döntő hányadát (>80\%) feljavított ketrecekben tartják, míg Hollandiában, Dániában, Svédországban, Németországban, Ausztriában és Luxemburgban a nemketreces tartásmód a meghatározó. A NÉBIH (2019) [38] adatai szerint hazánkban a tojótyúkok 83,0\%-a feljavított ketrecekben, 15,5\%-a alternatív rendszerben (mélyalom és volier), míg mintegy 1,5\%-a szabad- és biotartásban termel. Hazánkban a Nyugat-Európában jellemző fogyasztói tudatosság még kevésbé van jelen, a tojás iránti keresletet fóként az uniós átlagnál alacsonyabb vásárlóerő határozza meg [36].

Bár a köztudatban még mindig él a koleszterinnel kapcsolatos tévhit, mely befolyásolja a tojásfogyasztást, a fogyasztók ma már felismerik a tojásban lévő fehérjék, vitaminok és ásványi anyagok által nyújtott egészségügyi előnyöket. A táplálkozás- és orvostudományok képviselői napjainkban egyre inkább elismerik, hogy a tojás magas tápértékủ élelmiszer, mely létfontosságú vitaminokban és ásványi anyagokban gazdag. Ennek eredményeként az elmúlt évek során számos ország (köztük Ausztrália, Egyesült Királyság, Kanada, USA, Új-Zéland) táplálkozástudományi és egészségügyi intézménye megszüntette a tojás fogyasztásával kapcsolatos korlátozásokat, sőt ma már javasolja a tojás rendszeres fogyasztását az egészséges táplálkozás részeként [33, 21], ugyanakkor arra vonatkozóan, hogy milyen mértékű tojás fogyasztása egészséges, eltérő ajánlások érhetőek el a hazai és nemzetközi forrásokban. Ma már egyre inkább elismert az a tény, mely szerint a tojás egy „ételcsoda”, melynek biológiai értéke azonos az anyatejével, közel 40-féle, köztük baktericid, erős antigén és vérnyomáscsökkentő hatású fehérjét tartalmaz. Emellett 18 különböző aminosav található benne, melyből 9 esszenciális. A tojás magas tápértékű élelmiszer, nagy arányban találhatóak meg benne létfontosságú vitaminok és ásványi anyagok. Mindemellett a telített- és telítetlen zsírsavakat optimális arányban tartalmazza, s eközben nem tartalmaz szénhidrátot és transzzsírokat. Az elmúlt években számos tanulmány $[61,48,35]$ foglalkozott a tojásfogyasztás emberi szervezetre gyakorolt hatásával. Az eredmények azt mutatják, hogy a tojás számos olyan tápanyagot is tartalmaz, amelyek túl az alapvető táplálkozáson jelentős egészségmegőrző szereppel is bírnak. A közhiedelemmel ellentétben egy tojásban mindössze 190-210 mg koleszterin van, miközben a napi anyagcsere szükséglet fedezéséhez egy felnőtt szervezet napi kb. $3000 \mathrm{mg}$ koleszterint termel. Fontos megjegyezni, hogy az emberi szervezet napi állatifehérje-szükséglete a legolcsóbban és a legkisebb 
környezeti terhelés mellett a tojással fedezhető. Amellett, hogy alapvető élelmiszer, funkcionális tulajdonságaiból fakadóan fontos egészségmegőrző szerepet tölt be, s emellett könnyen dúsítható jótékony összetevőkkel. Pozitív tulajdonságai között kell megemlíteni, hogy segíti az agymúködést, a magzati fejlődést, az immunrendszert, csökkenti a daganatos és a kardiovaszkuláris megbetegedések, valamint a korral összefüggő szembetegségek, az érszúkület, és a trombózis kialakulásának és az időskori izomerő- és izomtömeg-csökkenés előfordulásának kockázatát [27, 17, $52,49,33,41,32,4,19,54]$.

\section{Módszer}

A tanulmány célja, hogy feltárja és összehasonlítsa a különböző tartástechnológiák fenntarthatóságbeli, minőségi és élelmiszerbiztonsági kérdéseit, valamint a fogyasztók egészségére és a tojásfogyasztásra ható tényezőit, a témához kapcsolódó nemzetközi szakirodalmak és adatbázisok szintetizálása révén. A releváns hazai szakirodalmak mellett törekedtünk a legfrissebb nemzetközi eredmények feldolgozására is. Ez a kvalitatív kutatási módszer feltáró jellegű, lehetővé teszi a vizsgált terület részletes megismerését, illetve korábbi kutatási eredmények és azok körülményeinek feltárását és összehasonlítását. Az így kapott eredmények nem számszerüsíthetők és nem mérhetők, e vizsgálatok célja a különböző szabályszerűségek feltárása és megértése.

\section{Eredmények}

A fogyasztók számára ma már az egyik legfontosabb szempont az élelmiszerválasztás során, hogy a termék fogyasztása biztonságos és egészséges legyen, vagyis ne tartalmazzon olyan anyagokat, amelyek veszélyeztethetik az egészségüket (mikroorganizmusok, mikotoxinok, peszticidek, antibiotikumok stb.). A közelmúltbeli táplálkozási trendekkel összhangban tehát a fogyasztók egészséges, kiegyensúlyozott élelmiszertermékeket igényelnek, így a tojás esetében is egyre nagyobb figyelmet fordítanak annak megváltozott minőségére. Emellett egyre nagyobb érdeklődés mutatkozik az alternatív módon előállított baromfitermékek iránt is. Ugyanakkor a fogyasztók többsége a tojás vásárlása során nem rendelkezik kellő információval a különböző tartásmódok közti különbségekről, s jellemzően úgy vélik, hogy az egyes tartásrendszerekben a tojások minősége és beltartalmi értéke eltérő. Számos fogyasztó úgy véli, hogy a szabad- és ökológiai tartásból származó tojás egészségesebb és jobb minőségü, mint a ketreces rendszerben termelt [46, 23, 47, 2, 16]. Az elmúlt években több kutatás is foglalkozott a különböző tartásmódok esetében tapasztalható minőségbeli, beltartalmi és termelési tulajdonságok vizsgálatával és az esetleges különbségek feltárásával. A kutatások egy része $[6,42,60]$ arra az eredményre jutott, hogy a tojás minőségét olyan termelési tényezók befolyásolják, mint a tyúk életkora, a genetika vagy a takarmányozás, ezért kiemelik, hogy a különböző tartásmódokból származó tojások minőségének összehasonlítását fenntartással kell kezelni. Ennek ellenére a tanulmányok egy része [13, 22, 11, 50, 42, 44] bizonyította a tartásrendszerek esetében meglévő minőségbeli különbségeket. KRALIK et al. (2013) [23] eredményei szerint a szabadtartásból származó tojás és annak sárgája nagyobb súlyú, s utóbbi intenzívebb színü, míg a ketreces rendszerben termelt termék héja vastagabb volt. Míg az egyéb, a tojás minőségét kifejező mutatók (pl. fehérje és héj súlya, a fehérje és a sárgája $\mathrm{pH}$ értéke) értékét nem befolyásolta a tartásmód. Ezzel szemben PERIĆ et al. (2016) [42] vizsgálata során a szabadtartásból származó tojások esetében jobb héjminőséget tapasztaltak, azonban a tojások sárgája halványabb színű volt, mint a ketreces rendszerben előállított termékeknél.

A minőségi tulajdonságok mellett több tanulmány is foglalkozik a ketreces és nemketreces termelésből származó tojások beltartalmi értékeiben tapasztalható különbségekkel. MATT et al. (2009) [30] kutatási eredményei szerint statisztikailag igazolható különbség mutatható ki a hagyományos és a biotartásban nevelt tyúkok tojásai között, vizsgálataik során a biotojások kalcium tartalma lényegesen alacsonyabb volt, mint a hagyományos ketrecből származóké, ezzel szemben a koleszterin- és a káliumkoncentráció magasabb volt az organikus tartásmód esetében. KÜÇÜKYLMAZ et al. (2012) [24] eredményei is ezt erősítik meg, az ökológiai rendszerben termelt tojások sárgája esetében alacsonyabb omega-3 szintet mértek, mint a hagyományos rendszerben előállított tojásokban. Fontos azonban megjegyezni, hogy a különböző tartásmódok esetében 
alkalmazott takarmányozásban jelentős különbségek lehetnek, $\mathrm{s}$ mindez nagymértékben befolyásolhatja a tojás beltartalmi értékeit, így a tapasztalt különbségek erre is visszavezethetők adott esetben.

A minőségi tulajdonságok és beltartalmi értékek vizsgálata mellett fontos kitérni az egyes tartásmódok élelmiszerbiztonságra gyakorolt hatásaira is. A szakemberek szerint a tartásmód jelentősen befolyásolja a tojás felületén megtalálható baktériumok számát és a mikrobiális szennyezettség szintjét is. A tojások esetében az egyik legelterjedtebb vegyi szennyezést, a dioxinszerü vegyületek megnövekedett szintjét, jellemzően a szabad- és ökológiai tartással azonosítják [18]. Korábbi kutatások [21, 9, 18] alapján megállapítható, hogy az ökológiai tartásból származó termékek dioxin szintje magasabb, sok esetben meghaladta a megengedett értéket. Ennek oka lehet többek között, hogy a nemketreces rendszerek esetében a tojótyúkok - a takarmányon túl - számos dioxinforrással érintkezhetnek (talaj, növények, rovarok).

A nemketreces rendszerekben nagyobb gyakorisággal jelentkezhetnek bizonyos, fóként paraziták által okozott betegségek, éppen emiatt gyakoribbak lehetnek az állategészségügyi beavatkozások, valamint nagyobb mennyiségü állatgyógyszert és vakcinát használnak fel ezekben a tartásmódokban. Ennek következtében a ketrecmentes tartástechnológiákból származó tojások esetében magasabb lehet az antimikrobiális, az anthelmintikumok és a különböző kokcidiózis elleni szerek maradványainak kockázata. A vizsgálatok azt igazolták, hogy a hagyományos és a feljavított ketreces rendszer esetében szignifikánsan alacsonyabbak a tojáshéj szennyezettségének értékei mind az összes baktériumszám, mind az Escherichia coli tekintetében, mint a mélyalmos és madárházas rendszerekben [56, 25, 11, 6]. Mindez a nemketreces rendszerek esetében humánegészségügyi szempontból jóval nagyobb kockázatot jelent, amivel véleményünk szerint a fogyasztók sok esetben nincsenek tisztában.

Bár az állatvédő szervezetek és a fogyasztók egy része szerint a nemketreces rendszerek szemben a ketreces tartásmóddal - minden esetben az állatok jólétét szolgálják, tanulmányok igazolják, hogy a csoportnagyság növelésével elért nagyobb mozgási szabadság növeli a tollcsipkedés, a csonttörések, valamint a kannibalizmus megjelenésének kockázatát $[56,45,5]$. Továbbá NERNBERG (2018) [39] azt is igazolta, hogy a madárházas (volier) tartástechnológia esetében szemben más tartásmódokkal -magasabb lehet az elhullási arány, amely fóként a hipokalcémiának, a szellőztetésnek, a kloáka előesésnek, a lábbetegségnek, és a madarak megfázásának vagy megbetegedésének tulajdonítható.

A fent említett tényezők mellett fontos megjegyezni továbbá, hogy a modern tojástermelés jellemzően tőkeigényes, viszonylag nagy létesítményeket igénylő tevékenység, mely hosszú távú beruházást igényel [40]. Az EU-ban a feljavított ketrecre történő áttérés jelentős többletköltséget jelentett az ágazat szereplői számára, sőt a tojástermelőknek számos környezetvédelemre, állatjólétre és élelmiszerbiztonságra vonatkozó jogszabályt kell betartaniuk. Az EU-s előírásoknak való megfelelés miatt felmerülő többletköltségek a becslések szerint a termelési költségek mintegy 16\%át jelentették 2017-ben [58]. Mindez jelentős nemzetközi versenyhátrányt jelent az unió termelői számára.

A hagyományos tartásmódhoz képest az alternatív rendszerek kialakításához kapcsolódó többletköltségeken túl a termelési költségek is magasabbak, hiszen e rendszerekben romlik az termelés hatékonysága (alacsonyabb telepítési sűrűség, magasabb fajlagos munkaerő-felhasználás, magasabb fajlagos takarmányfelhasználás, magasabb energiafelhasználás, stb.). Az 1. és 2. táblázatban bemutatott összefüggéseket több tanulmány is alátámasztotta. TAUSON (2005) [56] eredményei magasabb takarmányfelvételt és nagyobb arányú alomtojást mutattak a nemketreces rendszerekben, különösen a mélyalmos rendszerben. AERNI et al. (2005) [1], SUMNER et al. (2010) [53], SEKEROGLU et al. (2010) [51] és ENGLMAIEROVÁ et al. (2014) [11] eredményei szintén igazolták, hogy a nemketreces rendszerekben szignifikánsan magasabb a takarmány felhasználás és ezáltal rosszabb a takarmányhasznosulás, mint a hagyományos és a feljavított ketreces rendszerben. Ezen túl PHILIPPE et al. (2020) [43] vizsgálatai során a madárházakban a tojásrakási arány alacsonyabb, míg az alomtojások száma magasabb volt. STADIG et al. (2016) [53] többek között a rosszabb munkaerő-felhasználás hatékonyságát is kiemelte. 
1. táblázat: A különböző tartási rendszerekre jellemző termelési mutatók I.

\begin{tabular}{|c|c|c|c|c|c|c|c|}
\hline \multirow{3}{*}{ Megnevezés } & \multicolumn{7}{|c|}{ Tartási rendszer } \\
\hline & \multirow{2}{*}{$\begin{array}{l}\text { Hagyományos } \\
\text { ketrec }\end{array}$} & \multicolumn{2}{|c|}{ Mélyalmos } & \multicolumn{2}{|c|}{ Szabadtartás } & \multicolumn{2}{|c|}{ Bio } \\
\hline & & $\begin{array}{l}\text { egy } \\
\text { szintes }\end{array}$ & $\begin{array}{l}\text { több } \\
\text { szintes }\end{array}$ & $\begin{array}{l}\text { egy } \\
\text { szintes }\end{array}$ & $\begin{array}{l}\text { több } \\
\text { szintes }\end{array}$ & $\begin{array}{c}\text { egy } \\
\text { szintes }\end{array}$ & $\begin{array}{l}\text { több } \\
\text { szintes }\end{array}$ \\
\hline $\begin{array}{l}\text { Telepítési sürüség } \\
\left.\text { (tyúk } / \mathrm{m}^{2}\right)\end{array}$ & 25,0 & 8,6 & 20,4 & 8,6 & 16,1 & 5,6 & 8,1 \\
\hline $\begin{array}{l}\text { Takarmányfelhasználás } \\
\text { (kg/tojás kg) }\end{array}$ & 1,99 & \multicolumn{2}{|c|}{2,28} & \multicolumn{2}{|c|}{2,33} & \multicolumn{2}{|c|}{2,59} \\
\hline $\begin{array}{l}\text { Tojástermelés (tojás / } \\
\text { betelepített tyúk) }\end{array}$ & 338 & \multicolumn{2}{|c|}{318} & \multicolumn{2}{|c|}{302} & \multicolumn{2}{|c|}{276} \\
\hline $\begin{array}{l}\text { Munkaerő hatékonyság } \\
\text { (tyúk/FTE) }\end{array}$ & 60000 & 25000 & 35000 & 25000 & 30000 & 8000 & 12000 \\
\hline
\end{tabular}

Forrás: [10]

2. táblázat: A különböző tartási rendszerekre jellemző termelési mutatók II.

\begin{tabular}{|l|c|c|c|c|c|}
\hline \multirow{2}{*}{ Megnevezés } & \multicolumn{5}{|c|}{ Tartásmód } \\
\cline { 2 - 6 } & $\begin{array}{c}\text { Hagyományos } \\
\text { ketrec }\end{array}$ & $\begin{array}{c}\text { Berendezett } \\
\text { ketrec }\end{array}$ & $\begin{array}{c}\text { Többszintes } \\
\text { almos }\end{array}$ & $\begin{array}{c}\text { Mélyalmos } \\
\text { (egy szintes) }\end{array}$ & Kifutós \\
\hline $\begin{array}{l}\text { Takarmány- } \\
\text { felhasználás } \\
\text { (g/tyúk/nap) }\end{array}$ & 110 & 115 & 120 & 120 & 125 \\
\hline $\begin{array}{l}\text { Tojástermelés } \\
\text { (db/tyúk/év) }\end{array}$ & 280 & 275 & 270 & 270 & 260 \\
\hline $\begin{array}{l}\text { Munkaeró-felhasználás } \\
\text { (perc/tyúk/év) }\end{array}$ & 5 & n.a. & 10 & 16 & 22 \\
\hline $\begin{array}{l}\text { Állandó költség } \\
\text { (euró/tyúk-féróhely/év) }\end{array}$ & 2,00 & 3,60 & 3,60 & 3,90 & $>4,00$ \\
\hline
\end{tabular}

Forrás: [8] nyomán [5, 20]

Fontos azt is megjegyezni, hogy amellett, hogy a megnövekedett takarmányfelhasználás növeli az önköltséget - hiszen a termelési költségek jelentős hányadát a takarmányköltségek jelentik közvetett módon környezetvédelmi és azzal összefüggő fenntarthatósági kérdést is jelent, hiszen a magasabb takarmányszükséglet a takarmány-előállítás során nagyobb erőforrás-felhasználással (szántóföld terület, víz, kemikália, fosszilis erőforrások stb.) jár.

Számos tanulmány $[31,57,58,55]$ igazolja, hogy a ketreces rendszer a leggazdaságosabb tojástermelési mód. A ketreces és nemketreces rendszerek esetében eltérő az önköltség, $\mathrm{s}$ a hagyományos ketrecekhez képest a feljavított ketrecekben mintegy 6-13\%, míg az alternatív tartásmódok esetében $21 \%$ és $100 \%$ közti aránnyal lehet magasabb a tojás termelési költsége (3. táblázat). Az alternatív tartásmódok mellett Európában egyre népszerúbb a biotartás is, annak ellenére, hogy ily módon sokkal drágább a tojás előállítása, a magasabb takarmányfogyasztás vagy az alacsonyabb termelékenység következtében [28]. 
3. táblázat: Önköltség alakulása a különböző tartási rendszerekben

\begin{tabular}{|l|c|c|c|c|c|}
\hline \multirow{2}{*}{ Tartási rendszer } & \multicolumn{5}{|c|}{ Önköltség (\%) } \\
\cline { 2 - 6 } & $\begin{array}{l}\text { GERVAI - } \\
\text { GöNCZI (2011) } \\
\text { [15] cit. } \\
\text { Compassion in } \\
\text { World } \\
\text { Farming }\end{array}$ & $\begin{array}{l}\text { DEKKER et al. } \\
\text { (2011) [10] }\end{array}$ & $\begin{array}{l}\text { MATTHEW - } \\
\text { SUMNER } \\
\text { (2015) [31] }\end{array}$ & $\begin{array}{l}\text { VAN HORNE - } \\
\text { BONDT (2017) } \\
\text { [57]; VAN } \\
\text { HORNE (2019) } \\
\text { [58] }\end{array}$ & $\begin{array}{l}\text { SzÓLLÓSI et al. } \\
\text { (2019) [55] }\end{array}$ \\
\hline $\begin{array}{l}\text { Hagyományos } \\
\text { ketrec }\end{array}$ & $100 \%$ & $100 \%$ & $100 \%$ & $100 \%$ & n.a. \\
\hline Berendezett ketrec & $108 \%$ & n.a. & $113 \%$ & $106 \%$ & $100 \%$ \\
\hline Mélyalmos/Aviary & $121 \%$ & $112-115 \%$ & $136 \%$ & $123 \%$ & $139 \%$ \\
\hline Szabadtartás & $150 \%$ & $115-117 \%$ & n.a. & n.a. & n.a. \\
\hline Biotartás & $200 \%$ & $185 \%$ & n.a. & n.a. & n.a. \\
\hline
\end{tabular}

Forrás: [37]

A növekvő termelési költségek azt is jelentik, hogy a jövedelmező termelés érdekében az értékesítési árakban is meg kell jelennie a különbségeknek. Így a kereskedelmi láncok esetleges változtatása, a ketrecmentes rendszerek előtérbe helyezése előtt, fontos kérdés, hogy az adott ország/régió fogyasztói képesek-e, illetve hajlandóak-e kifizetni a magasabb értékesítési árat az alternatív rendszerekben termelt tojásokért? Hiszen amennyiben a fogyasztók, vagy azok egy része nem hajlandó többet fizetni az alternatív módon előállított termékekért, az a forgalom visszaesését jelentheti az üzletekben, amely ismét válaszút elő állíthatja ezek vezetését, s mindez hatással lesz a termelőkre is. BEJAEI et al. (2015) [3] fogyasztói szokások vizsgálatára vonatkozó eredményei is rámutatnak arra, hogy a piac heterogén, a fogyasztók jelentős részét (kevésbé képzett, idősebb, árérzékeny, nagyáruházakban vásárlók, szórólapokból tájékozódók, és az állatjóléti szempontokat kevésbé előtérbe helyező fogyasztók) nem érdekli a tojás előállításának módja és legtöbbször az ár alapján döntenek. CHANG et al. (2010) [7] és LUSK (2018) [29] hasonlóan kiemelik, hogy a legtöbb fogyasztó nem hajlandó többet fizetni a ketrecmentes termelésből származó tojásért. MESÍAS et al. (2010) [34] megállapítja továbbá, hogy a vásárlás során az ár a legfontosabb tényező, s csak bizonyos fogyasztói csoportok hajlandóak megfizetni az alternatív tartástechnológiák során felmerülő többletköltséget.

\section{Következtetések}

Az elmúlt évek során számos tanulmány készült, főként Európában, annak vizsgálatára, hogy a különböző tartásmódok hogyan hatnak a tojás minőségére, tápanyagtartalmára, valamint a környezetre és a tojótyúkok jólétére, annak érdekében, hogy az ágazat szereplői, illetve vásárlói minél szélesebb körü információval rendelkezzenek a ketreces és nemketreces rendszerek közti különbségekről. Napjainkban a fogyasztók többsége a tojás vásárlása során nem rendelkezik kellő információval a különböző tartásmódok közti különbségekről, s jellemzően úgy vélik, hogy az egyes tartásrendszerekben a tojások minősége és beltartalmi értéke eltérő. A köztudatban elterjedt, hogy a szabad- és ökológiai tartásból származó tojás jobb ízủ és sárgább, s az ily módon előállított termékek választásával tesznek valamit az egészségük és az állatok védelme érdekében. A különböző tartásmódok aránya éppen ezért a fogyasztói igények függvényében változik. Az elmúlt években több kutatás is igazolta, hogy bár az étkezési tojás minőségét jellemzően olyan termelési tényezők befolyásolják, mint a tyúk életkora, a genetika vagy a takarmányozás, a tartásmód mégis jelentős hatást gyakorol a minőségi tulajdonságokra. A tanulmányok igazolták, hogy a ketreces rendszerek esetében nagyobb a tojás súlya, az esetek többségében jobb a tojáshéj minősége, szemben a nemketreces rendszerekkel. A vizsgálatok többsége megerősítette azt a tényt, mely szerint a szabadtartásból származó tojás sárgája intenzívebb színű, azonban fontos azt megjegyezni, hogy ezt a tulajdonságot jelentős mértékben befolyásolja a takarmányozás. Igazolásra került továbbá, hogy a ketreces rendszerek esetében kisebb arányban fordulnak elő állatgyógyszer maradványok és 
mikrobiális szennyeződések a tojás felületén, valamint alacsonyabb a tojás dioxin-szintje, mint a nemketreces tartásmódból származó termékeknél. Az ismert információk tükrében megállapítható, hogy bár a környezet- és egészségtudatosság, valamint az állatjólét kérdésének népszerüségének növekedésével egyre nagyobb az igény az alternatív, nemketreces tartásmódokból származó termékek iránt, azonban a kutatási eredmények alapján nem a ketrecmentes termelés jelenti a legjobb megoldást a környezeti, társadalmi és gazdasági szempontból fenntartható tojásellátásra.

\section{Köszönetnyilvánítás}

A publikáció elkészítését az EFOP-3.6.1-16-2016-00022 számú, Debrecen Venture Catapult Program című projekt támogatta. A projekt az Európai Unió támogatásával, az Európai Szociális Alap társfinanszírozásával valósult meg.

\section{Irodalomjegyzék}

[1] Aerni, V., Brinkhof, M.W.G., Wechsler, B., Oester, H., Fröhlich, E. (2005): Productivity and mortality of laying hens in aviaries: A systematic review. World's Poultry Science Journal, 61, 131-143.

[2] Anderson, K.E. (2011): Comparison of fatty acid, cholesterol, and vitamin A and E composition in eggs from hens housed in conventional cage and range production facilities. Poultry Science 90: 1600-1608 DOI: 10.3382/ps.201001289

[3] Bejaei, M., Wiseman, K., Cheng, K.M. (2015): Developing logistic regression models using purchase attributes and demographics to predict the probability of purchases of regular and specialty eggs. British Poultry Science, 56, 425435.

[4] Bertechini, A.G., Mazzuco, H. (2013): The Table Egg: a Review. Ciênc agrotec 37(2): 115-122. DOI: 10.1590/S141370542013000200001

[5] Bessei, W. (2011): Az árutojás-termelés átállási gondjai. Baromfiágazat 11(3): 62-69.

[6] Cepero, R., Hernándiz, A. (2015): Effects of housing systems for laying hens on egg quality and safety. https://www.wpsa-aeca.es/aeca_imgs_docs/17564_texto\%20ricardo\%20 cepero_2015-60\%20english.pdf

[7] Chang, J.B., Lusk, J.L., Norwood, F.B. (2010): The price of happy hens: A hedonic analysis of retail egg prices. Journal of Agricultural and Resource, 2010, 35, 406-423.

[8] Damme, K. (2011): Faustzahlen zur Geflügelwirtschaft. Geflügeljahrbuch 2011. Verlag Eugen Ulmer. Stuttgart. 58-76.

[9] De Vries, M., Kwakkel, R.P., Kijlstra, A. (2006): Dioxins in organic eggs: a review. NJAS-Wageningen Journal of Life Sciences 54(2): 207-221. DOI: 10.1016/S1573-5214(06)80023-O

[10] Dekker, S.E.M., de Boer, I.J.M., Vermeij, I., Aarnink, A.J.A., Groot Koerkamp, P.W.G. (2011): Ecological and economic evaluation of Dutch egg production systems. Livestock Science, 139, 109-121. DOI: 10.1016/j.livsci.2011.03.011

[11] Englmaierová, M., Tůmová, E., Charvátová, V., Skřivan, M. (2014): Effects of laying hens housing system on laying performance, egg quality characteristics, and egg microbial contamination. Czech Journal of Animal Science 59(8): 345-352. DOI:10.17221/7585-CJAS

[12] EC (2020): EU Market Situation for Eggs, 20 May 2020. Brussels: European Commission, DG Agriculture and Rural Development, Committee for the Common Organisation of the Agricultural Markets. https://ec.europa.eu/info/foodfarming-fisheries/farming/facts-and-figures/markets/overviews/market-overview-sector_en (20.05.2020.)

[13] Ferrante, V., Lolli, S., Vezzoli, G., Guidobono Cavalchini, L. (2009): Effects of two different rearing systems (organic and barn) on production performance, animal welfare traits and egg quality characteristics in laying hens. Italian Journal of Animal Science 8(2): 165-174. DOI:10.4081/ijas.2009.165

[14] Fisher, C., Bowles, D. (2002): Hardboiled Reality: animal welfare-friendly egg production in a global market. Royal Society for the Prevention of Cruelty to Animals.

[15] Gervai P., Gönczi K. (2011) Taktikák technológiaváltásra. Haszon Agrár. V. évfolyam. 2011/6. Budapest. 33-35 p.

[16] Guyonnet, V. (2012): Eggs and egg products: Consumers' attitudes, perceptions and behaviours. XXIV. World's Poultry Congress 5-9 August - 2012. Salvador - Bahia - Brazil

[17] Herron, K.L., Fernandez, M.L. (2004): Are the Current Dietary Guidelines Regarding Egg Consumption Appropriate? Journal of Nutrition. 134 (1) 187-190. DOI: 10.1093/jn/134.1.187

[18] Holt, P.S., Davies, R.H., Dewulf, J., Gast, R.K., Huwe, J.K., Jones, D.R., Waltman, D., Willian, K.R. (2011): The impact of different housing systems on egg safety and quality. Poultry Science, 90 (2011), pp. 251-262. DOI: $10.3382 /$ ps.2010-00794

[19] Horn P. (2011): A tartási rendszerek versenyképességének esélyei a különböző erőforrások és a növekvő fogyasztói igények szorításában. „Baromfitermelés eredményesen 2011” szimpózium. 2011. október 25. Budapest.

[20] Horn, P.; Sütő, Z. "(2014): A világ baromfihús-termelése és az előállítás versenyképessége. Acta Agraria Kaposváriensis. 18 (1), pp. 14-29.

[21] Kijlstra, A. (2005): The role of organic and free range poultry production systems on the dioxin levels in eggs. Proceedings of 3rd SAFO workshop 16-18 September 2004, Falenty, Poland. pp. 83-90. https://pdfs.semanticscholar.org/12b2/9a6b5e5092bfoooo 9630a92bc588ce69f382.pdf

[22] Kralik, G., Škrtić, Z., Suchý, P., Straková, E., Gajčević, Z. (2008): Feeding fish oil and linseed oil to laying hens to increase the n-3 PUFA in egg yolk. Acta Veterinaria Brno, 77, 561-568. 
[23] Kralik, Z., Radišić, Ž., Grčević, M., Kralik, G. (2013): Comparison of table eggs quality originating from hens kept in different housing systems. Proceedings of XV European Symposium on the Quality of Eggs and Egg Products and XXI European Symposium on the Quality of Poultry Meat / Petracci, Massimiliano - Bergamo: The Italian Branch of The World's Poultry Science Association, 2013, 1-5.

[24] Küçükyılmaz, K., Bozkurt, M., Herken, M.N., Çınar, M. (2012): Effects of Rearing Systems on Performance, Egg Characteristics and Immune Response in Two Layer Hen Genotype. Asian-Australasian Journal of Animal Sciences, 25 (4) pp. 559-568 http://dx.doi.org/10.5713/ajas.2011.11382

[25] Lay, D.C., Fulton, R.M., Hester, P.Y., KArcher, D.M., Kjaer, J.B., Mench, J.A., Mullens, B.A., Newberry, R.C., Nicol, C.J., O'Sullivan, N.P., Porter, R.E. (2011): Hen welfare in different housing systems. Poultry Science., 90 (2011), 278294 https://doi.org/10.3382/ps.2010-00962

[26] Leenstra, F.R., Maurer, V., Galea, F., Bestman, M.W.P., Amsler, Z., Visscher, J., Vermeij, I., van Krimpen, M.M. (2014): Laying hen performance in different production systems; why do they differ and how to close the gap? Results of discussions with groups of farmers in The Netherlands, Switzerland and France, benchmarking and model calculations. Eurpean Poultry Science. 78 (3) pp. 1-10. doi: 10.1399/eps.2014.53

[27] Légrády P. (2001): Tojás, táplálkozás, egészség. Maecenas Könyvkiadó, Budapest, 255 p.

[28] Lewko, L., Gornowicz, E. (2009): Effect of Housing System on Egg Quality in Laying Hens. Annals of Animal Science 11(4) pp. 607-616. doi: 10.2478/v10220-011-0012-O

[29] Lusk, J.L.(2018): Consumer preferences for cage-free eggs and impacts of retailer pledges. Agribusiness, 35, 129148.

[30] Matt D., Veromann E., Luik A. (2009): Effect of housing systems on biochemical composition of chicken eggs. Agronomy Research 7 (Special issue II) pp. 662-667.

[31] Matthews, W.A., Sumner, D.A. (2015): Effects of housing system on the costs of commercial egg production. Poultry Science, 94, 552-557.

[32] McNamara, D.J. (1997): Cholesterol intake and plasma cholesterol: an update. Journal of the American College of Nutrition. 16 (6) 530-534.

[33] McNamara, D.J. (2010): Advances in Eggs and Egg Products. Egg Processors International Session Presentation. International Egg Commission (IEC), Paris, URL: https://www.internationalegg.com/ corporate/downloads/details.asp?id=439

[34] Mesías, F.J., Martínez-Carrasco, F., Martínez, J.M., Gaspar, P. (2010): Functional and organic eggs as an alternative to conventional production: A conjoint analysis of consumers' preferences. Journal of the Science of Food and Agriculture, 91, 532-538. DOI: 10.1002/jsfa.4217

[35] Miranda, J.M., Anton, X., Redondo-Valbuena, C., Roca-Saavedra, P., Rodriguez, J.A., Lamas, A., Franco, C.M., Cepeda, A. (2015): Egg and egg-derived foods: Effects on human health and use as functional foods. Nutrients. 7. 706729. DOI: $10.3390 /$ nu7010706

[36] Molnár Sz. - Szőllősi L. (2015): Fogyasztási és vásárlási szokások Magyarországon, Baromfiágazat, 15(3) pp. 6o-68.

[37] Molnár Sz., Szőllősi L. (2020) Sustainability and Quality Aspects of Different Table Egg Production Systems: A Literature Review. Sustainability. 12(19):7884. DOI: 10.3390/su12197884

[38] NÉBIH (2019): Nyilvántartott tojótyúk-tartó telepek, Nemzeti Élelmiszerlánc-biztonsági Hivatal. https://portal.nebih.gov.hu/-/nyilvantartott-tojotyuktarto-telepek.

[39] Nernberg, L. (2018): Cost Differential between Cage-Free Laying Systems. Poultry World. 3 August 2018. URL: https://www.poultryworld.net/Eggs/Articles/2018/8/Cost-differential-between-cage-free-laying-systems$317512 \mathrm{E} /$

[40] Ochs, D., Wolf, C.A., Widmar, N.J.O., Bir, C. (2018): Consumer perceptions of egg-laying hen housing systems. Poultry Science, 97, 3390-3396. DOI: 10.3382/ps/pey205

[41] Perić, L., Rodić, V., Milošević, N. (2011): Production of poultry meat and eggs as functional food - challenges and opportunities. Biotechnology in Animal Husbandry, 27 (3) pp. 511-520. DOI: 10.2298/bah1103511p

[42] Perić, L., Đukić Stojčić, M., Bjedov, S. (2016): Effect of production systems on quality and chemical composition of table eggs. Contemporary Agriculture, 65 (3-4) pp. 27-31 DOI: 10.1515/contagri-2016-0014

[43] Philippe, F.X., Mahmoudi, Y., Cinq-Mars, D., Lefrançois, M., Moula, N., Palacios, J., Pelletier, F., Godbout, S. (2020): Comparison of egg production, quality and composition in three production systems for laying hens. Livestock Science, 232, 103917:1-103917:10. DOI: 10.1016/j.livsci.2020.103917

[44] Popova, T., Petkov, E., Ayasan, T., Ignatova, M. (2020): Quality of Eggs from Layers Reared under Alternative and Conventional System. Brazilian Journal of Poultry Science, 22 (1), eRBCA-2019-1172. Epub June 05, 2020 DOI: 10.1590/1806-9061-2019-1172

[45] Rodenburg, TB; Tuyttens, FAM; de Reu, K; Herman, L; Zoons, J; Sonck, B. (2008): Welfare assessment of laying hens in furnished cages and non-cage systems: an on-farm comparison. Animal Welfare 17(4): 363-373.

[46] Rodić, V., Perić, L., Vukeli, Ć.N., Milošević, N. (2006): Consumer's attitudes towards chicken meat produced in extensive systems. World's Poultry Science Journal, XII European Poultry Conference. Book of Abstracts, 62, pp.186187.

[47] Rodić, V., Perić, L., Pavlovski, Z., Milošević, N. (2010): Improving the poultry sector in Serbia: major economic constraints and opportunities. Worlds Poultry Science Journal 66(2), 241-250. DOI: 10.1017/So043933910000292

[48] Rong, Y., Chen, L., Zhu, T., Song, Y., Yu, M., Shan, Z., Sands, A., Hu, F.B. (2013): Egg Consumption and Risk of Coronary Heart Disease and Stroke: Doseresponse Meta-analysis of Prospective Cohort Studies. British Medical Journal. 346, 8539-8551. DOI: 10.1136/bmj.e8539

[49] Ruxton, C.H.S., Derbyshire, E., Gibson, S. (2010): The Nutritional Properties and Health Benefits of Eggs. Nutrition \& Food Science. 40 (3) 263-279. https://doi.org/10.1108/00346651011043961

[50] Samiullah, R.J.R., Chousalkar K.K. (2014): Effect of production system and flock age on egg quality and total bacterial load in commercial laying hens. J. Appl. Poult. Res. 23(1): 59-70. https://doi.org/10.3382/japr.2013-00805 
[51] Sekeroglu, A., Sarica, M., Demir, E., Ulutas, Z., Tilki, M., Saatci, M., Omed, H. (2010): Effect of different housing systems on some performance traits and egg qualities of laying hens. Journal of Animal and Veterinary Advances, 9, 1739-1744. DOI: 10.3923/javaa.2010.1739.1744

[52] Sparks, N.H.C. (2006): The hen’s egg - is its role in human nutrition changing? World‘s Poultry Science Journal, 62: pp. 308-315. https://doi.org/10.1079/WPS200599

[53] Stadig, L.M., Ampe, B.A., van Gansbeke, S., van den Bogaert, T., D’Haenens, E., Heerkens, J.L.T., Tuyttens, F.A.M. (2016): Survey of egg farmers regarding the ban on conventional cages in the EU and their opinion of alternative layer housing systems in Flanders, Belgium. Poultry Science, 95, 715-725. DOI: 10.3382/ps/pev334

[54] Szőllősi L., Molnár Sz., Molnár Gy., Horn, P., Sütő Z. (2017): A tojás mint alapvető és funkcionális élelmiszer táplálkozás-élettani jelentősége. Táplálkozásmarketing. IV. évfolyam, 2017/1-2. szám. pp. 7-22. DOI: $10.20494 / \mathrm{TM} / 4 / 1-2 / 2$

[55] Szőllősi, L., Szúcs, I., Huzsvai, L., Molnár, Sz. (2019): Economic issues of Hungarian table egg production in different housing systems, farm sizes and production levels. Journal of Central European Agriculture, 20, 995-1008. DOI: 10.5513/JCEA01/20.3.2284

[56] Tauson, R. (2005): Management and housing systems for layers - effects on welfare and production. World's Poultry Science Journal 61(3): 477-490. DOI:10.1079/WPS200569

[57] Van Horne, P.L.M., Bondt, N. (2017): Competitiveness of the EU Egg Sector, Base Year 2015: International Comparison of Production Costs; Report 2017-062; Wageningen Economic Research: Wageningen, The Netherlands, pp. 11-15.

[58] Van Horne, P.L.M. (2019): Competitiveness the EU Egg Sector, Base Year 2017: International Comparison of Production Costs; Report 2019-008; Wageningen Economic Research: Wageningen, The Netherlands, pp. 9-15.

[59] Windhorst, H.-W. (2017): Housing Systems in Laying Hen Husbandry-First Part. Zootecnia International. 4 July 2017. URL: https://zootecnicainternational.com/featured/housing-systems-laying-hen-husbandry/\#

[6o] Yenice, G., Kaynar, O., Ileriturk, M., Hira, F., Hayirli, A. (2016): Quality of Eggs in Different Production Systems Czech Journal of Food Sciences., 34, 2016 (4): pp. 370-376 DOI: 10.17221/33/2016-CJFS

[61] Zampelas, A. (2012): Still Questioning the Association Between Egg Consumption and the Risk of Cardiovascular Diseases. Atherosclerosis. 224 318-319. DOI: 10.1016/j.atherosclerosis.2012.08.024 